\title{
Academic staff expectations of undergraduate students with respect to their use of the library at the University of KwaZulu-Natal, Pietermaritzburg Campus
}

\author{
Dumisani Nkosi ${ }^{1}$, Athol Leach ${ }^{2}$ and Ruth Hoskins ${ }^{3}$ \\ University of KwaZulu-Natal, Library and Information Studies \\ leach@ukzn.ac.za; hoskinsr@ukzn.ac.za
}

\begin{abstract}
Received 22 November 2011
Accepted 25 May 2012

This study was based on a Master's dissertation which investigated the academic staff expectations of undergraduate students with respect to library use at the University of KwaZulu-Natal, Pietermaritzburg (UKZNP) campus. The specific objectives of the study were to determine whether academic staff encourage students to use the library, to determine the reason(s) for doing or not doing so and to determine the format(s) or way(s) in which this is done. The survey research method was used and the data was collected through a self-administered questionnaire. All 131 academic staff of the Faculty of Human and Management Sciences were surveyed. Seventy one academic staff responded yielding a response rate of 55\%. Most (86\%) academic staff expected and encouraged students to use the library at an undergraduate level. The most used "method" of doing so was verbally. Conclusions in line with the findings and research objectives were made and these were followed by recommendations which included that greater effort could be made by lecturers in referring and/or encouraging students to use the library.
\end{abstract}

Keywords: library use students, library use university students, library use academics

\section{Introduction and literature review}

The experience of the University of KwaZulu-Natal, Pietermaritzburg Campus subject librarians is that academic staff tend to give students tasks to complete without sufficient knowledge of whether their students have acquired the relevant skills necessary for retrieving the information using the library's resources (Kuhn 2003). This raises a number of questions, including the presumption made by academic staff that students will have the necessary skills for literature searching by the time they get to the university. This despite the fact that many students entering higher education institutions are, as a result of the shortcomings in the primary and secondary schooling system, unprepared with regard to the information skills required to study at tertiary level (Van Vuuren \& Henning 2001:81)

In a study conducted by Braimoh, Jegede and Moshoeshoe-Chadzingwa (1997) which was an assessment of the National University of Lesotho Library, the students indicated that they generally used the library to read lecturers notes. Students further revealed that they tended to use the library for other activities, such as social gatherings, rather than for locating, accessing and retrieving information. The reason for this is that many students were found to be lacking in the ability to locate their desired information sources using the library facilities (Braimoh, Jegede \& Moshoeshoe-Chadzingwa 1997). As Haynes (1996:2007) pointed out a number of years ago:

... students are faced with an overwhelming amount and variety of information, and they may not be able to deal with the unprecedented abundance of resources without some organizing principles, or concepts, that enable them to understand the significance and interrelatedness of knowledge.

To counteract this, librarians in many institutions have implemented orientation programmes in which students are expected to participate voluntarily. At the University of KwaZulu-Natal, Pietermaritzburg Campus, for instance, orientation programmes are offered at the beginning of each semester. Braimoh, Jegede and Moshoeshoe-Chadzingwa (1997) emphasized that university libraries are instrumental in providing students with information literacy skills. To do so means moving beyond library orientation to library instruction with both academic staff and librarians considering the latter "to be the primary means of teaching students those skills" (Ren 2000:3). According to Steyn and Maritz (2003:329) such skills should include:

1. Dumisani Nkosi was a Masters student of Library and Information Studies Programme, University of KwaZulu-Natal, South Africa.

2. Athol Leach is a lecturer in the Library and Information Studies Programme, University of KwaZulu-Natal, South Africa.

3. Ruth Hoskins $(\mathrm{PhD})$ is a senior lecturer in the Library and Information Studies Programme, University of KwaZulu-Natal, South Africa. 
... knowledge of key information sources for a specific field of study; the identification or description and subsequent formulation of relevant questions in order to find information for a specific field of study; the location, evaluation, analysis, organization and use of information for a variety of contexts; and the interpretation of information in written, numeric and graphic format.

Informal discussions held by the researchers with subject librarians at the University of KwaZulu-Natal, Pietermaritzburg Campus, suggest that academic staff have not, in the past, made sufficient effort to promote attendance at formal library instruction nor have they encouraged students to use the library when searching for information for their assignments. Suggestions from the librarians indicated that there needs to be a higher level of rapport between academic and library staff to develop the skills associated with information literacy and promote successful library use by students.

Academic faculties and library departments in the world of higher education are separate sectors that are working for a common vision, that of providing education to the students. Larsen (1998: 259) and Mugyabuso (1999: 133) emphasized the fact that libraries and academic faculties should be working as partners in the same business without which education and research success in the academic world are impossible. Mugyabuso (1999) pointed out that user education programmes should be integrated into the university curriculum and made compulsory and examinable components. While the design of courses and teaching and grading of assignments by the faculties are the major elements in a student's education (Larsen 1998), it is also important that this teaching is done in co-operation with the library. It could be argued that successful teaching is largely dependant on the library's resources and staff. It is in this regard that academic staff do need to communicate and work with library staff and it is in this respect that libraries and librarians are also contributing to the teaching and learning activities in conjunction with the academic staff.

Poor use by students of the academic library has been a major concern to many academic librarians (Stahl 1997). Linked to this concern is the inability of many students to locate, retrieve and use information sources in the library despite orientation programmes available to students to improve their library skills. It is in this context that librarians have felt that students are not getting enough encouragement to use the library from academic staff. Steyn and Maritz (2003:

3) assert that it is the task of academic staff to recommend and motivate students to use the library when compiling assignments. Once students are encouraged to do so, they could acquire their long-life learning skills. The students who depend on the lecturer will find themselves at a disadvantage in the workplace since there they will be expected to be able to gather their own information and work productively on their own (van Vuren \& Henning 2001: 82). Mugyabuso's (1999: 135) point that "most students will use the library material in their course only if professors require them to..." is an important one to bear in mind in this context as is Baker's point that many studies "have shown that only a small proportion of students use the library, and that most of their use is a function of faculty expectations" (Baker 1997). This suggests that if academic staff increase their expectations and continuously influence a larger proportion of students, there is the likelihood that the proportion of students using the library could increase. Students are referred to as having an interest in using the library mostly to complete assignments, while understandably, a few use it for recreational reading. Steyn and Maritz (2003) suggest that with appropriate motivation and encouragement, students are likely to use the library for their learning purposes as a priority rather than for other interests

The above does perhaps point to insufficient communication between the library and academic faculties (Larsen 1998). If the communication is not sufficient, concrete and reliable, this would, arguably, impact negatively on library use by students and ultimately on the quality of teaching and learning.

The question that also arises is whether academic staff themselves have the necessary knowledge of library resources needed to assist students in locating, retrieving and accessing information of interest to them and whether they encourage students, at all levels, to use the library for their studies. In terms of the latter point Adikata and Anwar (2006:108) in support of Mugyabiso above suggest that "Faculty members are considered to be the inspiring and motivating factor in student library use." The authors go on to add that "The central position enjoyed by faculty members as regards student library use seems not to be shared by any other party."

Zondi (1991), Bell (1990), Krige (2001), Mugyabuso (1999) and many more have involved themselves in research regarding library instruction and information literacy programmes in university libraries that aimed at providing basic skills to students for their information needs. However, these initiatives have not involved the academic staff in their implementation to any great extent if at all. This does beg the question as to whether this is due to insufficient communication between the academic and library staff in connection with the usage of the library resources for the learning needs of the students as well as the support system of education at large or a lack of knowledge or disinterest on the part of academic staff.

While there are some academic staff who appear to be unaware of the significant role the library could play in students' performance, studies indicate that students who use the library when preparing for their studies are likely to 
produce more comprehensive assignments than those who do not (Gentil 1999; Krige 2001; Zondi 1991). According to Braimoh, Jegede and Moshoeshoe-Chadzingwa (1997: 64) the heart of students' courses or subjects is in the library, therefore students need to be frequently encouraged by lecturers to use the library. At the University of KwaZulu-Natal, Pietermaritzburg, subject librarians are concerned about the number of students who do not use the library, use it poorly or have, seemingly, not been referred or encouraged to use the library by academic staff. This apparent lack of referral or encouragement by academic staff with regard to student library use to support both the teaching and learning taking place constituted the broad problem which the study investigated. The specific questions the study sought to answer were as follows:

- Do academic staff encourage students to use the library?

- What methods are employed to encourage students to use the library?

- What categories of information sources do academic staff expect students at different levels to be able to use?

- What are the library and information skills students are expected to have and who should provide those skills?

Research has been done in the past on a wide range of aspects concerning university libraries. While a perusal of the literature does point to research documenting, amongst other issues, faculty perceptions towards libraries, bibliographic instruction and student library use beginning in the 1930s (Baker 1997) the scarcity of research on faculty perceptions towards student library use generally and in developing countries in particular (Adikata and Anwar 2006:109) is evident and this brief introduction and literature review bears testimony to this scarcity. In fact, the only two directly relevant studies which were found were those by Adikata and Anwar (2006) who investigated faculty perceptions toward student library use in a Malaysian university and Baker (1997) who investigated similar perceptions in what is described as a "large urban community college."

This study, apart from addressing the lack of research in the area, could assist subject librarians at the University of KwaZulu-Natal, Pietermaritzburg Library to better understand academic staff expectations of undergraduate students with respect to their use of the library at UKZNP. The study could further raise an awareness of the library amongst academic staff. The study was confined to the University of KwaZulu-Natal, Pietermaritzburg campus, and to the academic staff in the Faculty of Human and Management Sciences.

\section{Methodology}

The study used the survey method. As Neuman (2000) points out, the survey method enables researchers to sample many respondents that would answer similarly designed questions, hence enabling the simultaneous measurement of variables. Babbie and Mouton (2001) maintain that the survey method is the dominant method when studying or measuring attitudes and orientation in a larger population. For data collection a questionnaire containing both openended and closed questions was designed and administered electronically via e-mail and hard copy through the University internal mail system, to the respondents for this study. The collected data was coded and analyzed using the software program SPSS.

The population of the study was the academic staff of the Faculty of Human and Management Sciences at the University of KwaZulu-Natal, Pietermaritzburg. At the time data was collected there were 130 academic staff in this Faculty and all of them formed part of the survey population. Given that the whole population was surveyed there was no need for a sample. Copies of the questionnaire were sent via the University internal mail system to the participants using the list of names and addresses obtained from the Faculty of Human and Management Science Calendar. Of the 130 questionnaires distributed, 71 were returned indicating a final response rate of 55\%.

\section{Findings and discussion}

This section focuses on the lecturers' expectations relating to various aspects of undergraduate students use of UKZNP library.

3.1 Academic staff expectations of undergraduate students' use of the library

A question was asked to establish whether respondents expect undergraduate students to use the library. The majority of academic staff, 61 (86\%) responded that they expect undergraduate students to use the library while, surprisingly, seven (10\%) responded that they do not. Unfortunately, those who did not expect undergraduate students to use the library did not give reasons for their responses. The high percentage of respondents who expect undergraduates to use the library underscores the importance of Makopi's (1998: 17) point that an institutional library should function to create an appropriate strategy for the education and orientation of library users so that they regard it as friendly place, hence using it frequently and confidently. The high percentage of respondents also, arguably, underscores the importance they attach 
to student library use in accordance with the findings of the study of faculty members of a Malaysian University (Adikata \& Anwar 2006) and that of faculty in a large urban community college (Baker 1997).

3.2 Reasons for not expecting undergraduate students to use the library

The seven (10\%) respondents who answered negatively to the above question unfortunately did not give reasons for their responses. It is possible that lecturers with no knowledge of the potential of libraries to provide information for their own individual interests could hardly expect students to use the library.

3.3 Levels at which undergraduate students are expected to use the library A follow-up question asked those 61 respondents who replied in the affirmative what academic level they expect their students to use the library. The findings are reflected in Table 1.

Table 1 Levels at which undergraduate students are expected to use the library

\begin{tabular}{lcc}
\hline Students' levels & Frequency & Percentages \\
\hline First year Level & 6 & $10 \%$ \\
Second Year Level & 1 & $2 \%$ \\
Third Year Level & 1 & $2 \%$ \\
All Levels & 51 & $84 \%$ \\
No response & 2 & $3 \%$ \\
Total & 61 & $100 \%$ \\
\hline \hline
\end{tabular}

Fifty nine (97\%) out of 61 respondents answered the question. The vast majority 51 (86\%) of academic staff indicated that they expect their students to use the library at first, second and third year levels, whereas only one (2\%) responded that students are expected to use the library at second and third year. There was little support from respondents for specifying a particular level. Baker (1997: 177) asserts that there is a small proportion of students using the library at a given institution and most of this use is to fulfill Faculty expectations. Lecturers need to be aware that students must use, develop and enhance information search skills at all levels of study.

3.4 Respondents' expectations of undergraduate students' library use

A question was asked in order to explore the purpose(s) academic staff expect students to use the library for. The results are depicted in Table 2.

Table 2 Purpose(s) respondents expect students to use the library

\begin{tabular}{lcc}
\hline Purpose(s) & Frequency & Percentages \\
\hline Background reading & 63 & $94 \%$ \\
Assignments/Essays & 65 & $97 \%$ \\
Recreational reading & 22 & $32 \%$ \\
\hline
\end{tabular}

Multiple responses received

As can be seen in Table 2 above, the vast majority of respondents 65 (97\%) answered that students should use the library to compile assignments and essays while slightly less $63(94 \%)$ said that the library should be used for background reading. Perhaps not surprisingly, only 22 (32\%) responded that students should use the library for recreational reading. The findings are in agreement with Makopi (1998: 17) who pointed out that students are expected to use the library for their assignment compilation, for the most part, as well as other study related purposes. Steyn and Maritz (2003: 2) notes that with appropriate motivation and encouragement, students are likely to use the library for their learning purposes.

3.5 Referral or encouragement of students to use the library

A question was asked to determine whether respondents referred or encouraged students to use the library. Of the 61 respondents who were asked, the vast majority of $59(88 \%)$ respondents stated that they refer or encourage students to use the library while two (3\%) replied that they do not do so. This is a positive finding. In addition, since lecturers are thus arguably aware that the library can help to extend students' course related knowledge, they (lecturers) could integrate library use into their teaching (Makopi 1998: 17). According to Steyn and Maritz (2003: 3) it is essentially the task of academic staff to recommend and motivate students to use the library when compiling assignments. 
3.6 Manner in which students are referred or encouraged to use the library A fixed response question was presented to the respondents in order for them to indicate the manner in which they referred or encouraged students to use the library. The results are depicted in Table 3.

Table 3 Manner in which students are referred or encouraged to use the library

\begin{tabular}{lcc}
\hline Referral manner & Frequency & Percent \\
\hline Verbally during lectures & 59 & $100 \%$ \\
Specified in courses handouts & 53 & $90 \%$ \\
Verbally during tutorials & 25 & $42 \%$ \\
Assignment requirement & 54 & $92 \%$ \\
Taking students to library & 16 & $27 \%$ \\
Other & 4 & $7 \%$ \\
\hline
\end{tabular}

Multiple responses received

All academic staff, 59 (100\%) who responded to this question replied that they verbally encourage students to use the library. Sixteen $(27 \%)$ answered that they do so by taking students to the library. The idea of students' referral and encouragement to use the library is emphasized by Troll (2001: 10) and Steyn and Maritz (2003: 3) who assert that apart from teaching, lecturers must motivate and recommend students to use the library while doing their assignments. Essentially, lecturers should refer or encourage library use to students regardless of the method or format as long as it is pertinent to the referral and encouragement purposes. Steyn and Maritz (2003:3) pointed out that lecturers should try, as a means of referring students to use the library, to give assignments in which library resources have to be used.

3.7 Encouragement of undergraduate students to consult subject librarians

A question was asked to determine whether respondents encouraged students to consult the subject librarians for help. Of the 61 respondents, the majority of $47(77 \%)$, indicated that they do encourage students to consult subject librarians for help whereas 12 (19\%) said that they do not. Ren (2000: 328) asserts that since the advent of ICTs in libraries, librarians have become increasingly important. Knowledgeable librarians, with ability and willingness, can contribute positively to a university's teaching and learning programme. Students therefore need to be encouraged to liaise with them for information of interest (Haynes 1996: 202; Ren 2000: 238).

3.8 Categories of information sources students are expected to be able to use at different levels of study The 61 respondents were asked to indicate the categories of information sources they expected students to be able to use at different levels of study. The findings are depicted in Table 4.

Table 4 Categories of information students are expected to be able to use at different levels of study

\begin{tabular}{lcccc}
\hline Information Sources & First Year & Second Year & Third Year & All Levels \\
\hline Short Loan & $7(11.4 \%)$ & $3(5 \%)$ & $2(3.2 \%)$ & $55(90 \%)$ \\
Reference Collection & $7(11.4 \%)$ & $17(28 \%)$ & $6(10 \%)$ & $7(11.4 \%)$ \\
General book stock & $7(11.4 \%)$ & $5(8 \%)$ & $8(13.1 \%)$ & $59(97 \%)$ \\
Journals & $5(8 \%)$ & $13(21 \%)$ & $28(46 \%)$ & $18(26 \%)$ \\
Index and Abstract-print & $4(7 \%)$ & $7(11.4 \%)$ & $39(64 \%)$ & $2(3.2 \%)$ \\
Index and Abstract-electronic & $4(7 \%)$ & $6(10 \%)$ & $40(66 \%)$ & $6(10 \%)$ \\
Internet resources & $6(10 \%)$ & $12(20 \%)$ & $25(41 \%)$ & $19(31.1 \%)$ \\
Inter-Library Loan & $4(7 \%)$ & $13(21 \%)$ & $23(38 \%)$ & $18(26 \%)$ \\
OPAC & $6(10 \%)$ & $3(5 \%)$ & $15(25 \%)$ & $41(67 \%)$ \\
Subject Librarian & $9(15 \%)$ & $4(7 \%)$ & $14(23 \%)$ & $35(57 \%)$ \\
\hline
\end{tabular}

Multiple responses received

The majority of teaching staff, $59(97 \%)$, answered that they expected students to be able to use the general books at all levels of their undergraduate studies while a very small minority of two (3.2\%) expected students to be able to use the library's electronic information sources, like OPAC, SABINET, LISA at their third year levels. It was evident that with some information sources, there was an increased expectation that students should have knowledge of their use, particularly by third year. Troll (2001) argues that since information sources contain information pertinent to students' 
learning interests, students should, irrespective of the level of study, have relevant knowledge of these sources in order to be able to use the library efficiently.

3.9 Library skills and competencies students are expected to have Respondents were asked what library and information skills and competencies they expected their students to have in order to master course content. The results are presented in Table 5.

Table 5 Library skills and competencies students are expected to have

\begin{tabular}{lcc}
\hline Skills/Competencies & Frequency & Percent \\
\hline Physical orientation & 54 & $89 \%$ \\
Knowledge of resources & 59 & $97 \%$ \\
Searching specific resources & 41 & $67 \%$ \\
Using OPAC & 56 & $92 \%$ \\
Topic analysis & 42 & $68 \%$ \\
Evaluating information & 41 & $67 \%$ \\
Referencing & 48 & $78 \%$ \\
Other & 3 & $5 \%$ \\
\hline
\end{tabular}

Multiple responses were received

Out of the 61 respondents who answered this question, a vast majority of $59(97 \%)$ replied that they expected students to have knowledge of the resources held by the library. Interestingly, referencing at $48(78 \%)$, topic analysis at $42(68 \%)$ and evaluating information at $41(67 \%)$ were all competencies respondents expected students to have. Given that organizing, preserving and utilizing information in libraries has largely changed from manual to electronic, students need to acquire competencies in using information sources in electronic format. Failure to do this will retard if not end students' interest in library use (Kuh and Gonyea 2003: 257). Steyn and Maritz (2003: 1) and van Vuren and Henning (2001: 81) pointed out that to be successful academically, students need to have skills in searching for information related to their studies, using electronic library databases such as OPAC, SABINET, LISA, EBSCOHOST as well as CD-ROM format to name a few.

3.10 Provision of library and information skills for undergraduate students

A question was asked to determine from where respondents expected their students to acquire library and information skills. The results are depicted in Figure 1.

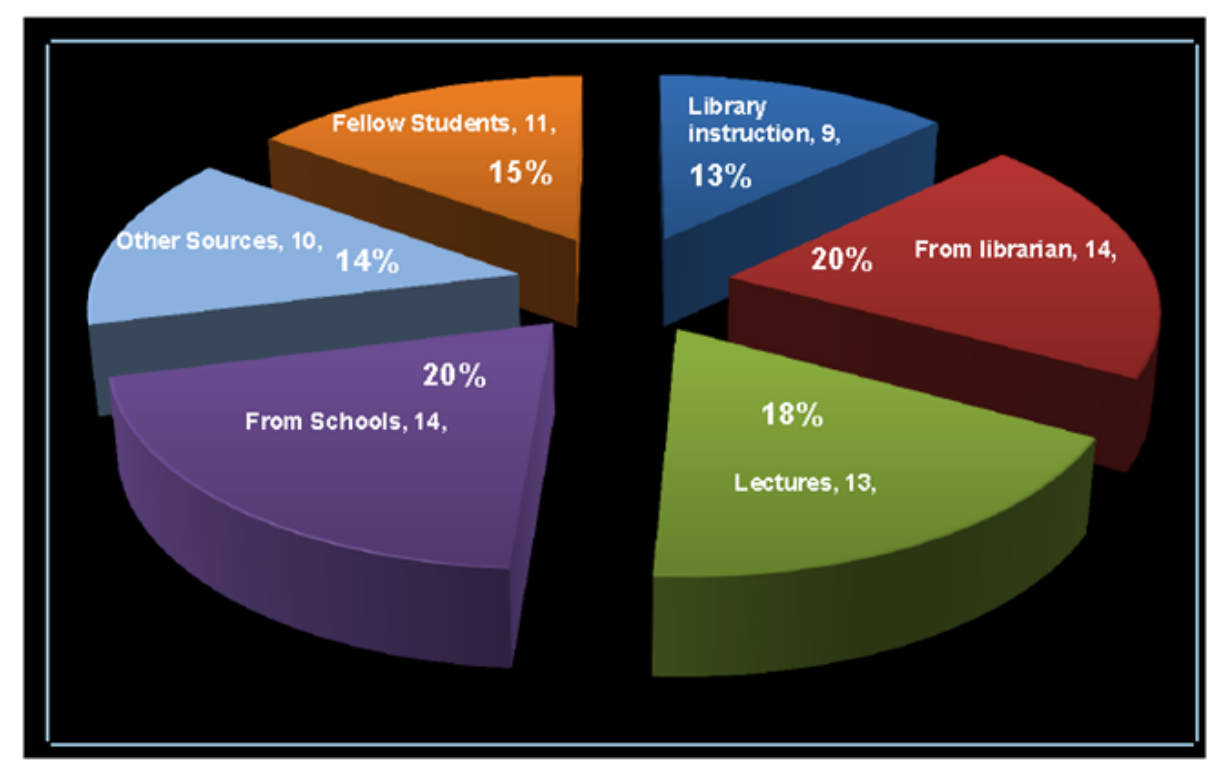

Figure 1 Sources of library and information skills provision to students 
Fourteen (20\%) of the 71 respondents indicated that students should acquire library skills from either a librarian or while still at school. Nine (13\%) respondents, expected students to acquire library skills from library instruction. It was clear that respondents expected schools to contribute to students' education in library skills, but in the absence of libraries in the majority of schools in South Africa this is perhaps an unrealistic expectation. Kuh and Gonyea (2003: 257) believed that if library staff move the extra mile through 'team-teach' library instruction with faculty colleagues, students are likely to acquire the requisite library skills.

3.11 Administering surveys or tests to establish if students have the requisite skills Respondents were asked whether they have surveyed or tested students to establish whether or not they have the requisite library and information skills. The results are depicted in Table 6.

Table 6 Administering surveys or tests to establish if students have the requisite skills

\begin{tabular}{lcc}
\hline Responses & Frequency & Percentages \\
\hline Yes & 7 & $10 \%$ \\
No & 55 & $77 \%$ \\
No response & 9 & $13 \%$ \\
Total & 71 & $100 \%$ \\
\hline \hline
\end{tabular}

Sixty two (87\%) out of 71 respondents replied to this question. The majority of respondents $55(77 \%)$ answered that they had not undertaken a survey or test in order to establish if students had requisite skills, while seven (10\%) replied that they had done so. None of the seven (10\%) respondents who indicated that they have undertaken a survey or test described the survey or test as asked in question.

A majority of $64(90 \%)$ teaching staff revealed that they have not undertaken a survey or test in order to establish if students have the requisite library and information skills while seven (10\%) replied that they had done so. Unfortunately, none of these seven described the survey or test.. One could question whether, given the time constraints of the academic year, conducting tests to gauge student knowledge of library use is feasible.

3.12 Awareness of difficulties students have when using the library A small majority of $30(53 \%)$ academic staff stated that they were aware of difficulties students have when using the library and information sources. Of those thirty, $24(42 \%)$ elaborated, stating that students have difficulty in getting information sources with ease, while six (11\%) replied that students lack adequate knowledge of using library resources. It is possible that if academic staff do not determine whether or not students have the requisite library and information skills, it would be more difficult for them to be aware of the difficulties students may encounter later (Lau 2001).

3.13 The benefits of library instruction to the students

Academic staff were asked whether the library instruction requested was of benefit to students.

The majority of $26(89 \%)$ out of $29(100 \%)$ respondents eligible to answer this question replied that the library instruction was of benefit to students. The three (10\%) who responded negatively did not explain why. For library instruction to be beneficial, it was important to elucidate to both lecturers and students that libraries are valued resources and an integral part of academic institutions, and hence should be fully utilized. According to Ren (2000:328), "library instruction has the potential to enable individual students to engage in electronic information searches on their own and it not only teaches skills but also cultivates self-efficacy". This is also supported by Haynes (1996: 206) who maintained "that library instruction provides a means of introducing database options, shortening the learning curves, allaying anxiety of computer phobia, and improving the quality of search methods and results". While it is evident that respondents in the study were supportive of library instruction in imparting the requisite information skills to students, the "strong beliefs about the important role for librarians in teaching the process of finding information" held by academics in a large community college in the United States (Baker 1997) was not shared by the majority of respondents in the present study.

\section{Conclusions and recommendations}

The conclusions reached were guided by the research questions of the study. The research questions and the conclusions relating to each question are given.

\subsection{Do academic staff in their teaching encourage students to use the library?}

- Ninety seven percent of those respondents who expected students to use the library stated that they referred and encouraged students to use the library. Eighty five percent of the respondents who participated in this study indicated that they expected undergraduate students to use the library. Eighty six percent of respondents also indicated that 
their students should use the library at first, second and third year level. Academic staff pointed out that students should use the library for assignment and essay compilation, while slightly less indicated that the library should be used for background reading. This clearly indicates that academic staff do expect and encourage students to use the library and therefore demonstrate an awareness of the importance of the library in their teaching.

4.2 What methods are employed to encourage students to use the library?

- The main approach used to encourage students in library use was verbal encouragement. This was mentioned by all 59 respondents who indicated that they referred and encouraged students to use the library. A significantly smaller percentage (27\%) referred or encouraged students to use the library by taking them to the library, while an even smaller percentage of staff $(7 \%)$ responded that use of the library was encouraged on students' course handouts. Some academic staff (7\%) also pointed out that student use of the library is one of the course requirements. It is thus evident that academic staff did encourage their students to use the library and they did so in a number of ways.

4.3 What categories of information sources do academic staff expect students at different levels to be able to use?

- When respondents were asked to identify categories of information sources students were expected to be able to use at different levels of study, it was found that students were expected to use general books at all levels of their undergraduate studies. In addition, it was evident that with the increasing number of electronic information sources available, there were increasing expectations that students should be able to use these resources at the third year level in particular. These expectations existed despite the fact that the majority of respondents were aware that students had difficulties when using the library and information resources.

- Most of the respondents (97\%) expected students to have knowledge of the resources held in the library. In addition, referencing, topic analysis and evaluation of information were all competencies respondents expected students to have knowledge of. Interestingly, however, the majority of respondents stated that they have never undertaken a survey or test in order to establish if students had the requisite library skills or not. It was also found that students were expected to acquire library knowledge and skills from a subject librarian or while still at school.

\subsection{Recommendations}

In the light of the findings and the conclusions listed above, the following recommendations are made regarding academic staff expectations of undergraduate students' use of the University of KwaZulu-Natal, Pietermaritzburg campus Main Library:

- It is evident that while academic staff both expect and encourage students to use the library, more could be done in this regard. Verbal encouragement does have its place and can be useful. However, a more proactive approach could be adopted by the academic staff including, for example, arranging with the subject librarians for group attendance by students and with subsequent instruction being linked to actual assignment requirements.

- Academic staff should include library instruction as a component of their course content especially for topic analysis, referencing and the evaluation of information resources which are common to most academic courses.

\section{References}

Adikata, A.A. \& Anwar, M.A 2006. Student library use: a study of faculty perceptions in a Malaysian University. Library Review, 55(2): 106-119.

Babbie, E. \& Mouton, J. 2001. The practice of social research. Oxford: University Press.

Baker, R.K. 1997. Faculty perceptions towards students library use in a large Urban

Community College. Journal of Academic Librarianship, 23(3): 177-182.

Bell, R.J. 1990. User education in the academic library: designing and evaluating a library instruction programme for underprepared students on the University of Natal, Pietermaritzburg Campus. MIS Thesis. Pietermaritzburg: University of Natal.

Braimoh, D., Jegede, J. \& Moshoeshoe-Chadzingwa, M.M. 1997. Library utilization and academic growth: an assessment of National University of Lesotho. African Journal of Library, Archive and Information Science, 7(1): 63-69.

Carr, R. 2006. What users want: an academic 'hybrid' library perspective. 46. [Online] http://www.ariadne.ac.uk/issue46/carr/ Accessed 24 November 2006.

Fagan, J. 2002. Students' perceptions of academic librarians. The Reference Librarian, 78: 131-148.

Gentil, B. 1999. User education: who needs it anyway. Innovation, 18: 29-35.

Haynes, E.B. 1996. Librarian-Faculty partnership in instruction. Advances in Librarianship, 20:191-222.

Krige, E.J. 2001. Evaluation of the "information retrieval skills- "Agri220" module

in the Faculty of Science and Agriculture at the University of Natal, Pietermaritzburg. MIS Thesis. Pietermaritzburg: University of Natal.

Kuh, G.D. and Gonyea, R.M. 2003. The role of academic library in promoting students engagement in learning. College and Research Libraries, 64(4): 256-282.

Kuhn, R. 2003. Personal communication. 15 July. 
Larsen, C.M. 1996. “What I want in a librarian”: a reference librarian's perspective. Reference and User Services Quarterly, 37(3): 259-161.

Lau, J. 2001. Faculty-librarian collaboration. Reference service review 29(2): 95-105.

Makopi, Z.N. 1998. The role of Transkei College of Education (TCE) library in the preparation of lectures: an analysis of the lecturers view. MIS. Thesis. Pietermaritzburg: University of Natal.

Mugyabuso, J.F.L. 1999. User education and information skills: a need for a systematic programme in African University Libraries. African Journal of Library, Archives and Information Science, 9-10: 129-141.

Neuman, L.L. 2000. Social research methods: qualitative and quantitative approaches. $4^{\text {th }}$ ed. Boston: Allyn and Bacon.

Ren, W.H. 2000. Library instruction and college students self-efficacy in electronic information searching. Journal of Academic Librarianship, 26(5): 323-328.

Renwick, S. 2005. Knowledge and use of electronic information resources by medical sciences faculty at The University of the West Indies. [Online] http://www.pubmedcentral.nih.gov/articlerender.fcgi?artid=545116 Accessed 15 November 2006.

Stahl, A.D. 1997. "What I want in a librarian”: one new faculty member's perspective. Reference and User Service Quarterly, 37(2): 133-136.

Steyn, M. \& Maritz, A. 2003. Information literacy in undergraduate teaching and learning programmes. [Online] http:// www.sun.ac.za/library/eng/help/IG\%20in\%20Programme/Inligtingsgeletterheid-e.ht Accessed 25 June 2007.

Troll, D.A. 2001. How and why are libraries changing? [Online] http://www.diglib.org/use/whitepaper.htm Accessed 26 June 2007.

Van Vuren, A. J. and J. C. Henning, J.C. 2001. User education in a flexible environment: an opportunity to stay relevant in the $21^{\text {st }}$ century. South African Journal of Libraries and Information Science, 66-67: 79-84.

Zondi, L. E. 1991. Library use skills and information seeking patterns of first-year students at the University of Zululand. MIS Thesis. Pietermaritzburg: University of Natal. 